\title{
Analytical techniques for characterization of raw materials in cell culture media
}

\author{
Chandana Sharma*, Barry Drew, Kevin Head, Rani Pusuluri, Matthew V Caple \\ From 22nd European Society for Animal Cell Technology (ESACT) Meeting on Cell Based Technologies \\ Vienna, Austria. 15-18 May 2011
}

\begin{abstract}
Raw materials are a critical part of any cell culture medium; therefore, it is of utmost importance to understand and characterize them for high-quality product. The raw material characterization (RMC) program at SAFC focuses on individual screening of raw materials both analytically and biologically. The goal of the program is to develop the best-in-class knowledge base of the raw materials used in SAFC's media formulations and their impact on performance of products.
\end{abstract}

\section{Background}

A prioritized list of 100 "high-risk" raw materials was developed based on a risk assessment performed within SAFC. This poster will focus on the analytical screening of certain "high-risk" raw materials within the prioritized list to identify any variability and critical contaminants present. In order to achieve this, orthogonal methods were used that include ultra-high performance liquid chromatography-mass spectrometry (U-HPLC/MS) for non-volatile polar components and gas chromatographymass spectrometry (GC/MS) for volatile non-polar materials. Inductively coupled plasma-optical emission spectrometry (ICP-OES) was also used to identify any trace metal contamination present. In addition, the solubility of the raw materials is also tested to identify any variability within a vendor or between different vendors.

\section{Results}

Figure 1 shows the process flow followed within the analytical RMC initiative. It describes how each raw material is screened and the strategy for analyzing any possible contaminant.

\section{Conclusions}

The orthogonal methods cited to characterize raw materials have proven to be robust and reliable for the

Cell Sciences and Development, SAFC, 13804 W 107 ${ }^{\text {th }}$ St, Lenexa, KS 66215, USA

Full list of author information is available at the end of the article intended purpose. The solubility experiment described for amino acids illustrates a significant difference in solubility limits of amino acids and establishes intra-

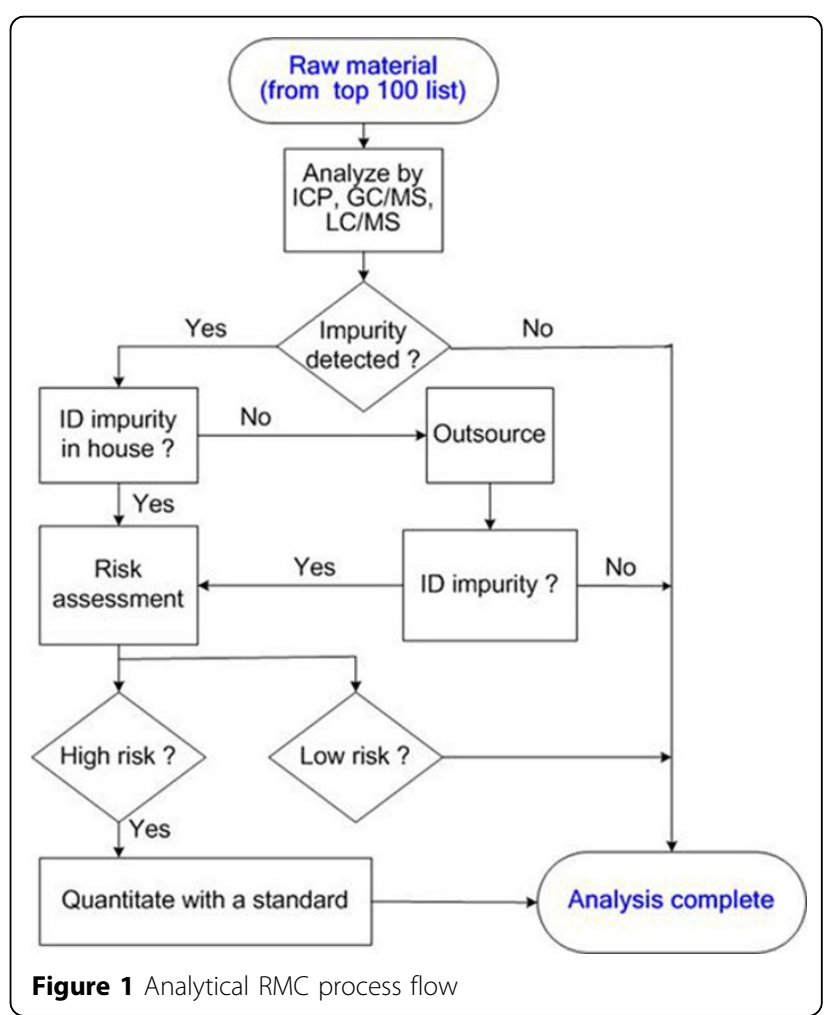


Table 1 Summary of solubility findings on multiple lots of three amino acids.

\begin{tabular}{ccccc}
\hline & \multicolumn{4}{c}{ Solubility in $\mathbf{1 0 0} \mathbf{~} \mathbf{l}$ of a neutral buffer } \\
\hline Vendor & $\begin{array}{c}\text { Lot } \\
\text { No. }\end{array}$ & $\begin{array}{c}\text { Lysine. } \mathbf{H C l} \\
(\mathbf{g})\end{array}$ & $\begin{array}{c}\text { Cystine.2 } \mathbf{H C l} \\
(\mathbf{m g})\end{array}$ & $\begin{array}{c}\text { Tyrosine.2Na } \\
(\mathbf{m g})\end{array}$ \\
\hline A & 1 & 5.0 & 12.4 & 175.1 \\
& 2 & 12.5 & 35.0 & 185.8 \\
& 3 & 10.0 & 35.2 & 185.5 \\
\hline B & 1 & 15.0 & 30.3 & 185.8 \\
& 2 & 12.5 & 50.8 & 195.2 \\
& 3 & 12.0 & 48.2 & 200.7 \\
\hline C & 1 & 60.0 & 32.0 & N/A \\
& 2 & 60.0 & 35.2 & N/A \\
& 3 & 60.0 & 32.8 & N/A \\
\hline D & 1 & 60.0 & N/A & N/A \\
& 2 & 60.0 & N/A & N/A \\
\hline
\end{tabular}

and inter-vendor variability. This program has helped SAFC get better insight into their suppliers' manufacturing processes. This is a long term initiative within the organization and the most important goal through the program is to develop a better understanding of raw materials to deliver superior products of the finest quality.

\section{Acknowledgements}

Our sincere thanks to Mr. T. Bower and Mr. S. Jones of Sigma-Aldrich for running samples on ICP and on LC/MS respectively.

Published: 22 November 2011

doi:10.1186/1753-6561-5-S8-P5

Cite this article as: Sharma et al:: Analytical techniques for

characterization of raw materials in cell culture media. BMC Proceedings 2011 5(Suppl 8):P5.
Submit your next manuscript to BioMed Central and take full advantage of:

- Convenient online submission

- Thorough peer review

- No space constraints or color figure charges

- Immediate publication on acceptance

- Inclusion in PubMed, CAS, Scopus and Google Scholar

- Research which is freely available for redistribution

Submit your manuscript at www.biomedcentral.com/submit 